\title{
On the growth of nucleation mode particles: source rates of condensable vapor in polluted and clean environments
}

\author{
M. Kulmala ${ }^{1}$, T. Petäjä ${ }^{1}$, P. Mönkkönen ${ }^{1}$, I. K. Koponen ${ }^{1}$, M. Dal Maso ${ }^{1}$, P. P. Aalto ${ }^{1}$, K. E. J. Lehtinen ${ }^{2}$, and \\ V.-M. Kerminen ${ }^{3}$ \\ ${ }^{1}$ Department of Physical Sciences, University of Helsinki, P.O. BOX 64, FIN-00014 University of Helsinki, Finland \\ ${ }^{2}$ Finnish Meteorological Institute and University of Kuopio, P.O. BOX 1627, FIN-70211 Kuopio, Finland \\ ${ }^{3}$ Finnish Meteorological Institute, Research and Development, Climate and Global Change, Sahaajankatu 20E, FIN-00880 \\ Helsinki, Finland
}

Received: 1 September 2004 - Published in Atmos. Chem. Phys. Discuss.: 29 October 2004

Revised: 1 February 2005 - Accepted: 4 February 2005 - Published: 10 February 2005

\begin{abstract}
.
The growth properties of nucleation mode particles were investigated. The variation of source rates of condensable vapors in different locations and environmental conditions was analyzed. The measurements were performed in background stations in Antarctica, in Finnish Lapland and Boreal Forest stations (SMEAR I and SMEAR II) as well as in polluted urban sites in Athens, Marseille and New Delhi. Taking advantage of only the measured spectral evolution of aerosol particles as a function of time the formation and growth properties of nucleation mode aerosols were evaluated. The diameter growth-rate and condensation sink were obtained from the measured size distribution dynamics. Using this growth rate and condensation sink, the concentration of condensable vapors and their source rate were estimated. The growth rates and condensation sinks ranged between $0.3-20 \mathrm{~nm} \mathrm{~h}^{-1}$ and $10^{-4}-0.07 \mathrm{~s}^{-1}$, respectively. The corresponding source rate of condensable vapors varied more than 4 orders of magnitude from $10^{3}$ to over $10^{7} \mathrm{~cm}^{-1} \mathrm{~s}^{-1}$. The highest condensation sink and source rate values were observed in New Delhi and the smallest values in Antarctica.
\end{abstract}

\section{Introduction}

Aerosol particles are ubiquitous in the Earth's atmosphere and affect our quality of life in many different ways. In polluted urban environments, aerosol emissions can affect human health through their inhalation (e.g. Donaldson et al., 1998), whilst globally, aerosols are thought to contribute to climate change patterns (e.g. Charlson et al., 1987). In recent

Correspondence to: M. Kulmala

(markku.kulmala@helsinki.fi) years, considerable effort has been devoted to understanding how aerosols directly affect the Earth's radiation budget by scattering and absorbing incoming solar radiation. Aerosols also affect the radiation budget indirectly by modifying many cloud properties such as their albedo and lifetime. It is generally thought that increases in aerosol concentrations will lead to brighter and more sustained clouds, thus providing additional planetary cooling.

In order to be able to better understand the health and climatic effects of atmospheric aerosols, the formation and growth processes of atmospheric aerosols should also be better understood (Kulmala, 2003). Nucleation, the formation of ultrafine particles detected at a few $\mathrm{nm}$, and subsequent growth to $\sim 100 \mathrm{~nm}$ in 1-2 days, has been observed frequently in the continental boundary layer. Such observations span from northern-most sub-arctic Lapland (Vehkamäki et al., 2004), over the remote boreal forest (Mäkelä et al., 1997; Kulmala et al., 1998, 2001b) and suburban Helsinki (Väkevä et al., 2000), to industrialised agricultural regions in Germany (Birmili et al., 2001) and also to coastal environments around Europe (O'Dowd et al., 1999). The atmospheric new particle formation rates have also been investigated by Weber et al. (1996, 1997), and the biogenic aerosol formation by Kavouras et al. (1998). A recent overview summarised the formation and growth properties in a global point of view (Kulmala et al., 2004), quantifying particularly the formation and growth rates of nucleation events, where available.

The main purpose of this paper is to analyse particle formation and growth events in detail in order to quantify the concentration of condensable vapors as well as their source rates. Some estimations on these quantities are already available (Kulmala et al., 2001a) for the Finnish boreal forest.

(C) 2005 Author(s). This work is licensed under a Creative Commons License. 
However, since such a multitude of studies has appeared on particle formation events all over the world (Kulmala et al., 2004), a more thorough analysis on the range of vapor concentrations and source rates is likely to be of interest also to regional and global modelers.

\section{Analytical expressions}

The observed nucleation mode growth, the concentration of condensable vapor and its source rate during the nucleation and growth events are analysed using two equations describing the rate of change of vapor concentration and particle growth (see Kulmala et al., 2001a). Considering condensable vapor molecules of some species, the time dependence of the vapor concentration (C) can be expressed (see also Kulmala et al., 1998) as

$\frac{d C}{d t}=Q-C S \cdot C$,

where $Q$ is the source rate of the vapor and CS is its condensation sink (see Eq. 4) to the pre-existing aerosol. The condensation itself is driven by the vapor pressure difference far away and on the surface of the pre-existing particle surface. In this work the vapor pressure at the surface is assumed to be zero, yielding a maximum mass flux of condensable vapor to the aerosol phase. With this assumption, an unknown activity coefficient plays no role in the condensation flux.

The growth-rate can be expressed as (Kulmala, 1988)

$$
\frac{d d_{p}}{d t}=\frac{4 m_{v} \beta_{m} D C}{d_{p} \rho}
$$

Here $d_{p}$ is particle radius, $m_{v}$ is molecular mass of condensable vapor, $D$ is diffusion coefficient, and $\rho$ is particle density. For the transitional correction factor for the mass flux $\beta_{M}$ we use the Fuchs-Sutugin expression (Fuchs and Sutugin, 1971). The equilibrium vapor pressure of the condensing species is assumed to be negligible. Equation (2) can be integrated from $d_{p, 0}$ to $d_{p}$ to obtain (Kulmala et al., 2001a):

$$
\begin{aligned}
C & =\frac{\rho}{\Delta t D m_{v}}\left(\frac{d_{p}^{2}-d_{p, 0}^{2}}{8}+\left(\frac{2}{3 \alpha}-0.312\right) \lambda\left(d_{p}-d_{p, 0}\right)\right. \\
& \left.+0.623 \lambda^{2} \ln \frac{2 \lambda+d_{p}}{2 \lambda+d_{p, 0}}\right)
\end{aligned}
$$

Here $\alpha$ is the mass accommodation coefficient (i.e. sticking probability, here assumed to be unity) and $\lambda$ is the mean free path. The growth rate $d d_{p} / d t$ and condensation sink $C S$ can be obtained directly from the size distribution evolution measurements.

The aerosol condensation sink determines how rapidly molecules will condense onto pre-existing aerosols and depends strongly on the shape of the size distribution (see e.g.
Pirjola et al., 1999; Kulmala et al., 2001a). The condensation sink $C S$ is obtained by integrating over the aerosol size distribution:

$$
C S=2 \pi D \int_{0}^{\infty} d_{p} \beta_{M}\left(d_{p}\right) n\left(d_{p}\right) d d_{p}=2 \pi D \sum_{i} \beta_{M} d_{p, i} N_{i}(4)
$$

where $n(d p)$ is the particle size distribution function and $N_{i}$ is the concentration of particles in the size section $i$.

After calculating the condensable vapor concentration (C) and condensation sink (CS) from size distribution measurements using Eqs. (3) and (4), respectively, the vapor source rate can be estimated from the following equation:

$Q=C S \cdot C$,

which is obtained directly from the Eq. (1) by making a pseudo-steady state assumption.

\section{Aerosol size distribution measurements}

\subsection{Instrumentation}

Sub-micron aerosol size distribution measurements are a necessary requirement for condensable vapor and its source rate estimations. In this study, calculations are based on similar instrumentation operated either campaignvise or continuosly in various locations. These measurements were conducted in the course of a few years. Due to this and the fact that during the campaigns also the sites themselves imposed demands on the instrumentation setups, differences in the detailed description of the measurement devices arised. However, in all places, a differential mobility particle sizer (DMPS) with a closed loop flow arrangement (Jokinen and Mäkelä, 1997; Aalto et al., 2001) was utilized to obtain size distributions. The time resolution was typically $10 \mathrm{~min}$ in which time aerosol $>3 \mathrm{~nm}$ in diameter (in Hyytiälä, Athens, Marseille, New Delhi and Antactica) was measured. The system used in Värriö had a slighly larger cutsize of $8 \mathrm{~nm}$ in diameter. The upper size limit varied between 600 and $1000 \mathrm{~nm}$.

More specifically, a DMPS systems consisted of two parallel devices. The first was used to characterize the size distrubution of ultra-fine particles (typically 3-20 nm), where the size classification with respect to electrical mobility equivalent diameter was obtained with a short $(0.109 \mathrm{~m})$ Viennatype (Winklmayr et al., 1991) Differential Mobility Analyzer (DMA). The particles were counted with a TSI 3025 Ultra-fine Condensation Particle Counter (Stolzenburg and McMurry, 1991). The other half of the DMPS-system was dedicated to Aitken and accumulation particles (typically 20-700 nm). It comprised of a longer $(0.28 \mathrm{~m})$ Vienna-type DMA and a TSI 3010 Condensation Particle Counter (Quant et al., 1992). Prior to the size classification, aerosol particles were exposed to a radioactive $\beta$-source, which ensured the Boltzmann charge equilibrium in the aerosol population and 
enabled particle classification based on their electrical mobility. Total sub-micron aerosol number concentrations were obtained from the integrated size distributions. Sheath flows in the DMAs adjusted at each site to yield the most useful measurement size range and time resolution. Typically the sheath flows varied between 5 to 10 , and 10 to $251 \mathrm{~min}^{-1}$ for long and short DMA, respectively.

The aerosol sampling inlet of the DMPS systems was located at $2 \mathrm{~m}$ height above ground at Hyytiälä and Värriö stations. In the campaigns, the inlet stucture extended up to $3 \mathrm{~m}$ heigh above the surface (Marseille and Athens). The DMPS system in New Delhi was placed in the 5th floor next to a window. The inlet tube was placed outside of the window so that the inlet was $15 \mathrm{~m}$ above the ground level and $0.5 \mathrm{~m}$ from the wall of the building. In Antarctica, the inlet was placed $2.5 \mathrm{~m}$ above the container roof, which was about $3 \mathrm{~m}$ above the ground. The sample air was led through a verticallyplaced, $60 \mathrm{~mm}$ steel tube with a total flow of $26.51 \mathrm{~min}^{-1}$. The sample was taken from the main flow and led to the DMPS system through a $30 \mathrm{~cm}$ long stainless steel tube having a diameter of $6 \mathrm{~mm}$.

The aerosol size distribution was obtained from the raw data through an inversion method, which included charging probabilities according to Wiedensohler (1988) and DMA transfer functions by Stolzenburg (1988) as well as counting efficiencies of the particle counters based on Mertes et al. (1995) for CPC 3010 and laboratory calibrations for CPC 3025 (Aalto, 2004). Losses in the inlet tube were estimated based on laminar flow diffusion theory (e.g. Brockmann, 2001). In the Marseille and Athens campaigns an external permapure drier was used to remove excess water from the aerosol particles. This ensured that the sampled aerosol population went through the sizing system as dry particles. This, in turn, increased losses in the sampling lines. The effect of the drier was not taken into account in the Athens data analysis.

During the Marseille and Athens intensive field campaigns, supermicron aerosol size distributions were measured with an Aerodynamic Particle Sizer (APS-3320, TSI Inc, USA). This instrument extended the measurement range up to approximately $10 \mu \mathrm{m}$ (Armendariz and Leith, 2002). The APS, however, used aerodynamic size as a basis of the classification whereas the DMPS used the electrical mobility equivalent diameter. They are related to each other through an unknown density of the particles. Combined size distributions from these two instuments was obtained through fitting the DMPS and the APS size distributions in a least-squares sense so that the largest sizes of the DMPS mached the lower boundary of the APS size distributions. The APS was not used in other locations, which therefore narrowed the observed size range. However, the effect of larger particles to the condensable vapor concentrations and source rate estimations were typically less than 5 per cent in Hyytiälä and coastal Mace Head site in Ireland (Dal Maso et al., 2002), which justified the neglection of the sink provided the super- micron particles in the rural and remote locations (Hyytiälä, Värriö and Antarctica). In the polluted urban site of New Delhi the absolute value of the sink provided by supermicron particles could be significantly higher than at cleaner sites, but its contribution to the overall sink was likely to be smaller. For the calculated condensable vapors, however, the ratio between sink in the sub- and supermicron particles is the most important factor. Based on this argument, the uncertainty of the estimated condensable vapor concentration caused by neglecting supermicron particles is probably lower in the polluted environment than in the cleaner regions.

\subsection{Measurement sites}

The aerosol size distribution measurements related to this study with DMPS-systems were conducted at six different locations: from Finnish Arctic (Värriö) to Boreal forest (Hyytiälä) and further south to the Mediterranean (Athens and Marseille) and India (New Delhi). The southernmost measurement site was located in Antarctica (Finnish research station Aboa). Such a variety in studied environments enabled us to achieve a maximal variability both in the condensable vapor concentrations and in the source rates of these vapors. Data were collected either campaignwise (Athens, Marseille and Antarctica) leading to datasets of 2-4 weeks or utilizing stable measurement facilities (Hyytiälä and Värriö), where the data set covered several years of measurements.

The SMEAR I station is located in Värriö $\left(67^{\circ} 46^{\prime} \mathrm{N}\right.$, $\left.29^{\circ} 35^{\prime} \mathrm{E}\right), 250 \mathrm{~km}$ north of the Arctic circle in Eastern Lapland and less than ten kilometres from the Finnish-Russian border. The DMPS measurements were done on top of a hill $390 \mathrm{~m}$ above sea level (a.s.l.). There are no towns or industry close by, and thus practically no local pollution. The nearest major pollution sources are Montschegorsk located $150 \mathrm{~km}$ to the East and Nikel located $190 \mathrm{~km}$ to the North of the station. The measured air is representative of the arctic boreal forest background when the air is not coming from these source areas.

The SMEAR II-station is located in Hyytiälä, Southern Finland $\left(61^{\circ} 51^{\prime} \mathrm{N}, 24^{\circ} 17^{\prime} \mathrm{E}, 181 \mathrm{~m}\right.$ a.s.l.). The terrain around the station is representative of the boreal coniferous forest. The 40-year old Scots pine (Pinus sylvestris $L$.) dominated stand is homogenous for about $200 \mathrm{~m}$ in all directions, extending to the north for about $1.2 \mathrm{~km}$. The largest city near the station is Tampere, ca. $60 \mathrm{~km} \mathrm{S-SW}$ of the measurement site. The terrain is subject to modest height variations. A more detailed discussion and evaluation on the aerosol instrumentation used in the SMEAR II station is given in Aalto et al. (2001); Kulmala et al. (2001a), and in the SMEAR I station by Vehkamäki et al. (2004).

The measurement site in Athens was located in Thrakomakedones ( $38^{\circ} 8^{\prime} 37^{\prime \prime} \mathrm{N}, 23^{\circ} 45^{\prime} 29^{\prime \prime} \mathrm{E}, 550 \mathrm{~m}$ a.s.1.). The site was located approximately $20 \mathrm{~km}$ north of the city centre of Athens, Greece in the foothills of mountain Parnitha. It is surrounded by suburban areas in the south and forests in the 

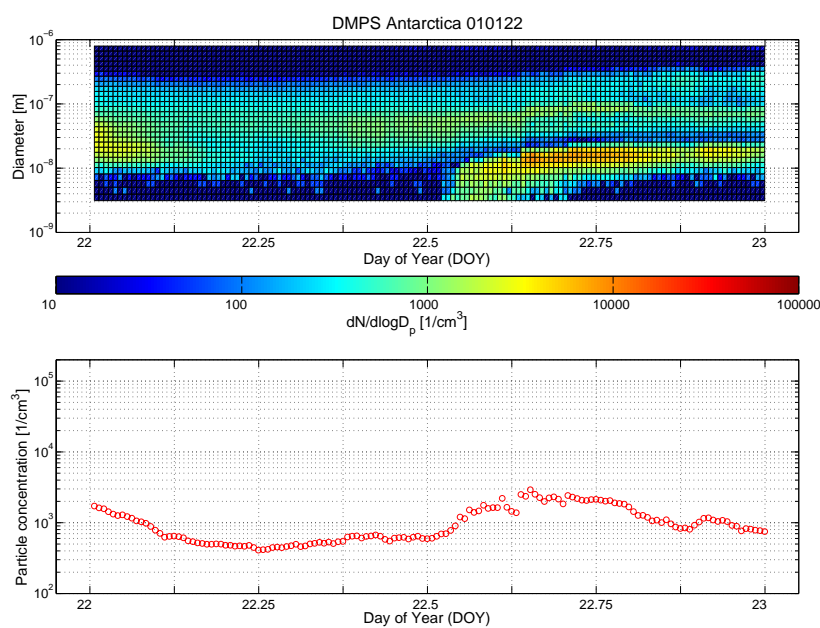

Fig. 1. Diurnal variation of Antarctica size distribution and total number concentration.
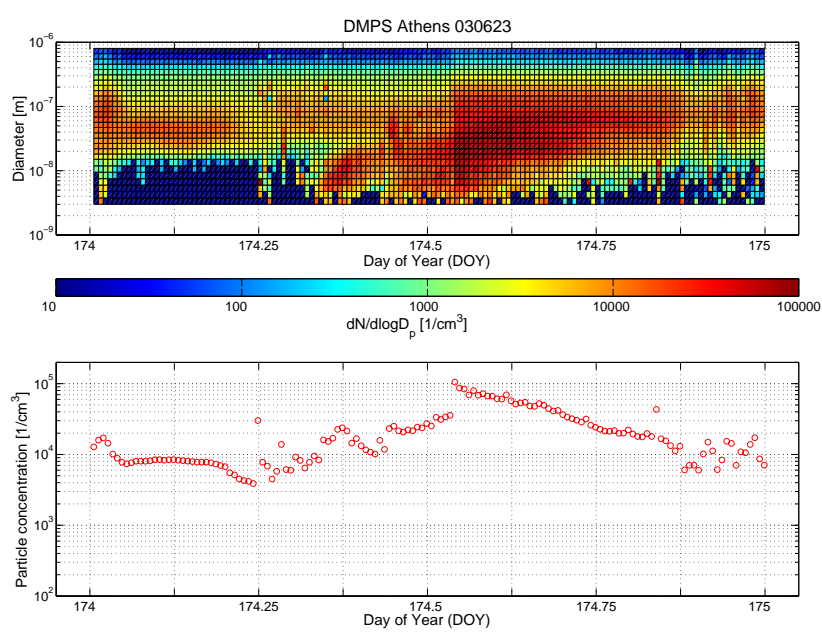

Fig. 2. Diurnal variation of Athens size distribution and total number concentration.

north. Due to the proximity of urban areas, the site can be categorized as urban background station. The measurement campaign in the Athens area was conducted between 10 and 26 July 2003.

The Marseille data set was obtained through a campaign held in Plan d'Aups village ( $43^{\circ} 19^{\prime} \mathrm{N}, 5^{\circ} 42^{\prime} \mathrm{E}, 700 \mathrm{~m}$ a.s.l.) approximately $40 \mathrm{~km}$ northeast from the city centre of Marseille, France. The measurements were conducted between 1 and 19 July 2002.

In India the field experiment was performed at India Habitat Centre (IHC/TERI) $\left(28^{\circ} 35^{\prime} \mathrm{N}, 77^{\circ} 12^{\prime} \mathrm{E}, 218 \mathrm{~m}\right.$ a.s.l. $)$ in New Delhi from 26 October to 9 November 2002. The measuring site was located next to a traffic line in a residential area a few kilometers south from one of the city centers (Connaught Place). For more details, see Mönkkönen et al. (2005).
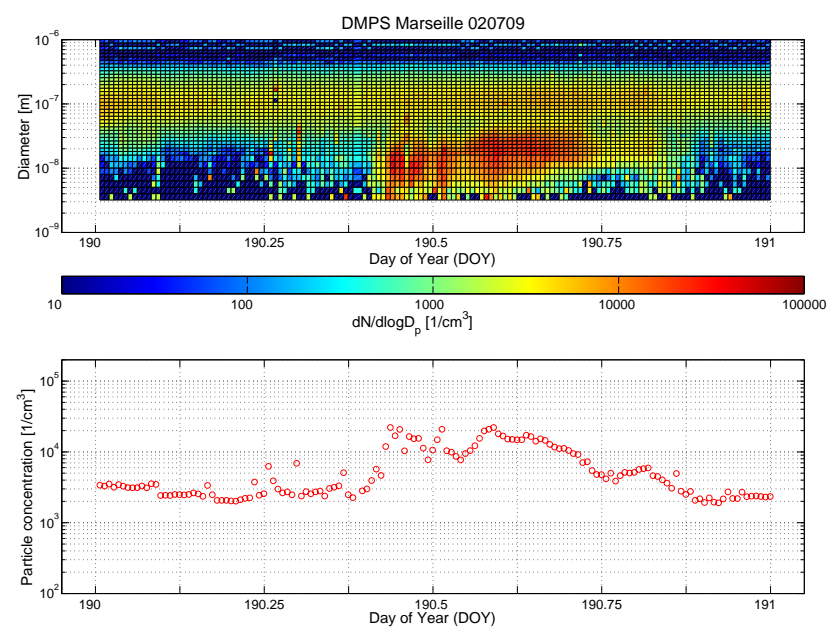

Fig. 3. Diurnal variation of Marseille size distribution and total number concentration.

In Antarctica measurements were conducted at Finnish Antarctic station, Aboa $\left(73^{\circ} 3^{\prime} \mathrm{S}, 13^{\circ} 25^{\prime} \mathrm{W}\right)$, between 5 and 22 January 2000 and between 1 and 26 January 2001. Aboa is located on nunatak Basen some $130 \mathrm{~km}$ from the coast line of Antarctica and $480 \mathrm{~m}$ above the sea level. The measurement site is described in more detail by Koponen et al. (2003).

\section{Results and discussion}

Four aerosol formation event days from measurement campaigns in Antarctica, Athens, Marseille and New Delhi as well as two days from continuous measurements performed at SMEAR I and II are presented in Figs. 1-6. In all these days, the submicron size distribution data showed a clear increase in the small-particle $(<10 \mathrm{~nm})$ concentration during the late morning, followed by the subsequent growth of these particles into Aitken and accumulation mode sizes throughout the afternoon and evening. The evolution of the size spectra illustrates thereby the growth of the nucleation mode up to sizes of the order of 50-100 nm over periods of about $10 \mathrm{~h}$. For each event period, the start and end times of the event, the nucleation mode growth rate and condensation sinks were determined from the experimental data.

During the observed particle formation events, the condensation sink was usually higher in more polluted areas. The highest value of CS $\left(5-7 \cdot 10^{-2} \mathrm{~s}^{-1}\right)$ was encountered in New Delhi, while in the European cities Athens and Marseille CS was significantly (5-10 times) lower (Table 1). In non-polluted areas like Värriö (SMEAR I) and Antarctica, the values of CS were some 50-100 times lower than those observed in New Delhi. Condensation sinks measured during the Hyytiälä (SMEAR II) events were on average somewhat larger than those during the Värriö (SMEAR I) events. 

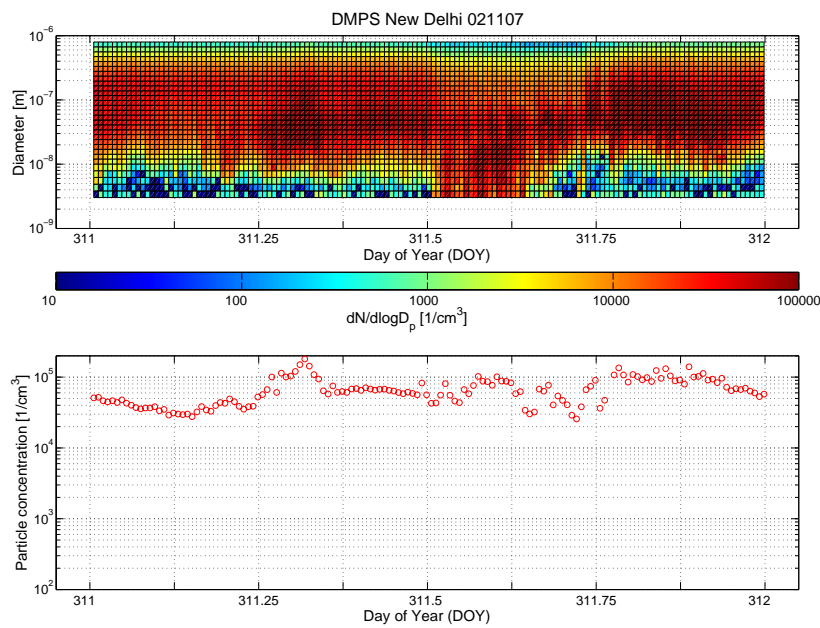

Fig. 4. Diurnal variation of New Delhi size distribution and total number concentration.

Taken into account the high seasonal variabitility of the ambient aerosol size distributions, the calculated condensation sinks and growth rates as well as estimated condensable vapor concentrations and source rates should be used with caution. This concerns particularly short field campaigns, in which the data set is quite limited. The long-term measurements, on the other hand, can be used to represent characteristic values of the region over the proposed period (SMEAR I: all seasons, SMEAR II: winters).

The typical submicron DMPS data correspond to "dried" dehydrated aerosol sizes, while the supermicron distributions were observed at ambient humidity corresponding to ambient "wet" aerosol sizes. Consequently, the response of the ambient aerosol to humidity-induced growth will also be reflected in the calculated condensation sink. The effect of particle hygroscopic growth factors on the calculated condensation sink has been investigated by Kulmala et al. (2001a). In the present study we have used dry condensation sinks, resulting in some uncertainties in our estimations. However, the typical overall underestimation of CS is between 5 and 50\%, which is minor considering the large differencies in its magnitude between the clean and polluted environments.

Using Eq. (3) we can estimate the vapor concentrations needed to explain the observed condensational growth and, furthermore, the source rate of the condensable vapor with the Eq. (5). These estimations depend, however, on the assumptions made for the properties of this condensable vapor, such as its molecular mass, its gas-phase diffusion coefficient and its mass accommodation coefficient on particle surfaces (see Kulmala et al., 2001a, for details). Luckily, the needed vapor concentration is only sensitive to the mass accommodation coefficient, since the product of the diffusion coefficient and mass of condensing molecules is practically almost constant. In any case, when proper rigorous condensation theory is used, the mass accommodation coefficient
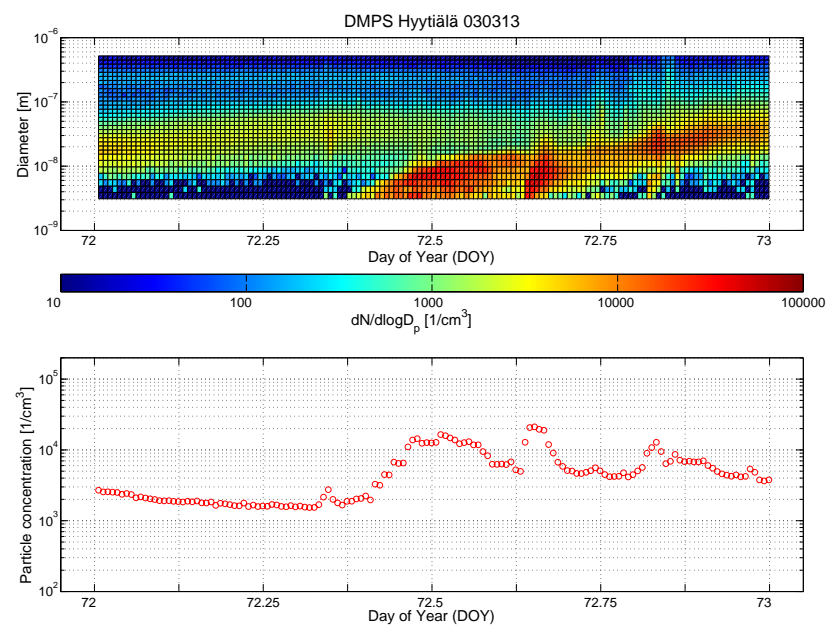

Fig. 5. Diurnal variation of Hyytiälä size distribution and total number concentration.
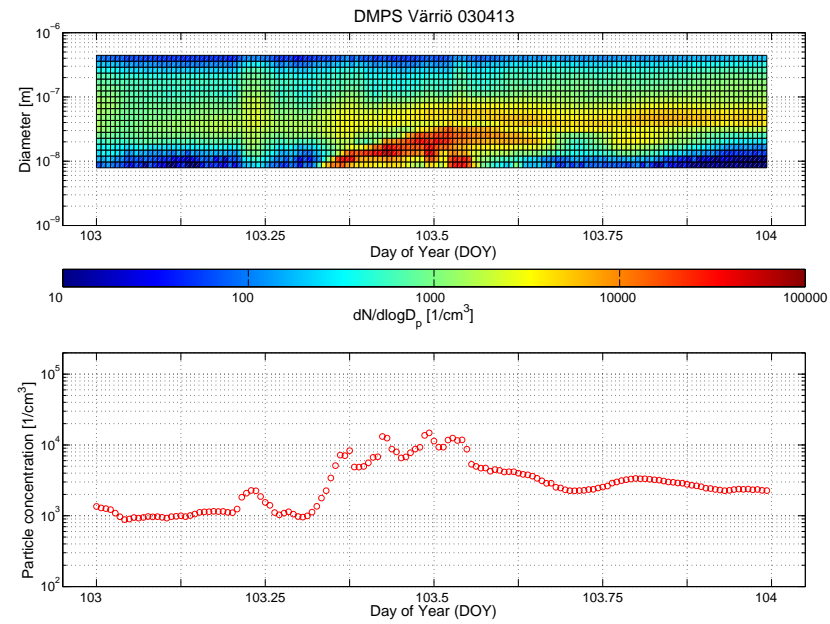

Fig. 6. Diurnal variation of Värriö size distribution and total number concentration.

of unity can be used. This is recently experimentally shown by Winkler et al. (2004). However, even the effect of mass accommodation on source rate (Q) is small (Kulmala et al., 2001a). Experimental parameters needed in the calculations of condensable vapor were determined with a maximum uncertainty of a factor of 2 . This uncertainty cannot explain the magnitude differences in the calculated concentrations and source rates of condensable vapors.

New particle formation events have been observed in both clean and polluted environments (Kulmala et al., 2004). In practise, new particle formation events cannot be observed unless the source rate of condensable vapors is high enough to induce a sufficiently large growth rate for the smallest nucleation mode particles. According to our analysis, the required source rates of $>10^{7} \mathrm{~cm}^{-3} \mathrm{~s}^{-1}$ in the most polluted environment (New Delhi) are 10-100 times larger than those 
Table 1. Observation sites, number of formation and growth events, minimum and maximum of condensation sink (CS), growth rate (GR), vapor concentration $(C)$ and source rate of vapor $(Q)$.

\begin{tabular}{lccccc}
\hline Site & \# events & $\mathrm{CS}\left(\mathrm{s}^{-1}\right)$ & $\mathrm{GR}\left(\mathrm{nm} \mathrm{h}^{-1}\right)$ & $\mathrm{C}\left(\mathrm{cm}^{-3}\right)$ & $\mathrm{Q}\left(\mathrm{cm}^{-3} \mathrm{~s}^{-1}\right)$ \\
\hline $\begin{array}{l}\text { New Delhi } \\
\text { 26 Oct.-9 Nov. 2002 }\end{array}$ & 8 & $5 \cdot 10^{-2}-7 \cdot 10^{-2}$ & $11.6-16.0$ & $15.8 \cdot 10^{7}-24.6 \cdot 10^{7}$ & $0.9 \cdot 10^{7}-1.4 \cdot 10^{7}$ \\
\hline $\begin{array}{l}\text { Marseille } \\
\text { 1 July-19 July 2002 }\end{array}$ & 10 & $3.2 \cdot 10^{-3}-1.5 \cdot 10^{-2}$ & $1.1-8.1$ & $1.5 \cdot 10^{7}-11.1 \cdot 10^{7}$ & $8.7 \cdot 10^{4}-1.3 \cdot 10^{6}$ \\
\hline $\begin{array}{l}\text { Athens } \\
\text { 1 June-26 June 2003 }\end{array}$ & 7 & $5.8 \cdot 10^{-3}-1.3 \cdot 10^{-2}$ & $2.3-11.8$ & $3.1 \cdot 10^{7}-16.2 \cdot 10^{7}$ & $2.6 \cdot 10^{5}-1.6 \cdot 10^{6}$ \\
\hline $\begin{array}{l}\text { Antarctica } \\
\text { Jan. 2000/2001 }\end{array}$ & 10 & $2.4 \cdot 10^{-4}-9.6 \cdot 10^{-4}$ & $0.3-2.7$ & $0.4 \cdot 10^{7}-3.7 \cdot 10^{7}$ & $0.9 \cdot 10^{3}-2.0 \cdot 10^{4}$ \\
\hline $\begin{array}{l}\text { SMEAR I } \\
\text { Värriö 1998-2002 }\end{array}$ & 147 & $0.6 \cdot 10^{-4}-3.6 \cdot 10^{-3}$ & $0.8-10.6$ & $1.1 \cdot 10^{7}-14.7 \cdot 10^{7}$ & $1.9 \cdot 10^{3}-4.8 \cdot 10^{5}$ \\
\hline $\begin{array}{l}\text { SMEAR II } \\
\text { Hyytiälä } \\
\text { winters 1997-2001 }\end{array}$ & 34 & $2 \cdot 10^{-4}-7 \cdot 10^{-3}$ & $1.3-5$ & $2.1 \cdot 10^{7}-8.2 \cdot 10^{7}$ & $5.0 \cdot 10^{3}-6.9 \cdot 10^{5}$ \\
\hline
\end{tabular}

in the European cities (Athens and Marseille) and roughly four orders of magnitude larger than those for our cleanest environments (Aboa and SMEAR I).

A question that immediately arises is whether the very large difference in the vapor source rates between the clean and polluted environments is realistic. Potential candidates for the condensable vapors responsible for the growth of nucleation mode particles are sulfuric acid and various organic vapors of low volatility. In the lower troposphere, gaseous sulfuric acid is produced mainly by the reaction of sulfur dioxide $\left(\mathrm{SO}_{2}\right)$ with the $\mathrm{OH}$ radical. The concentration of $\mathrm{SO}_{2}$ varies by a more than three orders of magnitude between the very clean and polluted environments (Rotstayn and Lohmann, 2002; Carmichael et al., 2003), whereas the concentration of the $\mathrm{OH}$ radical depends mainly on the intensity of solar radiation. By combining these things together, the source rate for gaseous sulfuric acid might well differ by the required four orders of magnitude between New Delhi and our cleanest environments.

The source rates of condensable organic vapors are very difficult to estimate because a large number of precursors for these vapors exist, because the relevant precursors probably differ between the different environments, and because the formation yields of condensable vapors from their precursors are likely to vary with time and location. Globally the production of secondary organic aerosols is likely to be dominated by biogenic precursors (Griffin et al., 1999; Tsigaridis and Kanakidou, 2003; Lack et al., 2004). Based on this it seems very likely that the source rate of condensable organic vapors does not decrease as fast as the source rate of gaseous sulfuric acid, when going away from the polluted environments. If this turns out to be true, our results would indicate that the contribution of sulfuric acid to the particle growth might be substantially larger in urban environments than in most clean locations. Some support for this view is obtained by comparing the recent results by Boy et al. (2004) and Stanier et al. (2004), showing that sulfuric acid is responsible of $10 \%$ and almost $100 \%$ of the particle growth in remote forested and polluted environments, respectively.

Observed growth rates of nucleation mode particles were surprisingly similar between the different measurement sites, differing on average by less than an order of magnitude. This can be explained by the close interdependence between $\mathrm{Q}$, CS and emissions. Namely, sources that emit both gaseous (precursors for condensable vapors) and particulate pollutants result in simultaneous increases in both Q and CS. Sources emitting only gaseous pollutants increase Q, which then leads to larger CS via an enhanced gas-to-particle transfer. The fact that Q and CS usually change in concert with each other balances variations in the condensable vapor concentration (Eq. 5) and thereby in the particle growth rate.

One interesting feature in our observations is that the growth rate of nucleation mode particles always exceeds $10 \mathrm{~nm} \mathrm{~h}^{-1}$ in New Delhi, and that growth rates $<1 \mathrm{~nm} \mathrm{~h}^{-1}$ can only be observed in the very clean environments. The probable reason for this is the strong interplay between the nuclei growth and their loss by coagulation: the larger the degree of pollution (larger $C S$ ), the faster small nuclei must grow to survive the coagulational scavenging onto larger preexisting particles (Kerminen et al., 2001; Kulmala et al., 2004). This feature also explains the larger average growth rates observed in more polluted environments, as well as the somewhat larger variability of the growth in the cleanest environments. 


\section{Conclusions}

In this study, the formation and growth of aerosol particles in the nucleation mode have been investigated using novel analytical tools. From the size spectra the diameter growth-rates and condensation sinks can be calculated. With this information, the concentration of condensable vapors and their source rate can be estimated. The analysis has been applied to analysis of aerosol formation events in six different sites, representing very different air pollution conditions.

The estimated source rate of condensable vapors was found to vary by up to four orders of magnitude between the most polluted (New Delhi) and the cleanest sites (Northern Finland and Antarctica) considered here. These high variations were necessary to explain the formation and subsequent growth of new particles in these sites. Preliminary indications were obtained on that the relative role of sulfuric acid and condensable organic vapors in the growth of nucleation mode particles in different environments, the sulfuric acid being more important in polluted areas.

Despite large variations in the vapor source rates, the growth rate of nucleation mode particles did not vary by more than 1-2 orders of magnitude between the different sites. The primary reason for this is that the large vapor source rates usually appear in concert with large condensation sinks, the overall effect of which is to balance the condensable vapor concentrations. The average particle growth rates increased, however, with the level of pollution. This can be explained by the fact the low particle growth rates cannot be observed in very polluted environments due to the effective scavenging of the smallest growing particles by the pre-existing aerosol population.

The estimation of vapor source rates and concentrations using this quite straightforward technique agrees well with box model studies, which included detailed aerosol dynamics (Kulmala et al., 1998, 2000). So it seems that despite the simplifications in the calculations the obtained estimations of the condensable vapors and its source rates is possible with the simple analytical method.

Current estimates on the magnitude of regional and global secondary aerosol formation rely almost entirely on modeling and are subject to large uncertainties. The approach introduced here provides a simple yet reasonably accurate way of calculating condensable vapor source rates based on field data and in very different environments. As such, our approach might be very useful for closure studies in which the vapor source rate is calculated independently using either aerosol measurements or modeled atmospheric chemistry. By combining our approach with suitable chemical measurements, we could ultimately estimate the relative contribution of condensable vapors - particularly of sulfuric acid - to the formation of secondary aerosols in different atmospheric environments.
Acknowledgements. The financial support from the Academy of Finland is acknowledged.

Edited by: J. Ström

\section{References}

Aalto, P.: Atmospheric ultrafine particle measurements, $\mathrm{PhD}$ thesis, Division of Atmospheric Sciences, University of Helsinki, 2004.

Aalto, P., Hämeri, K., Becker, E., Weber, R., Salm, J., Mäkelä, J. M., Hoell, C., O’Dowd, C. D., Karlsson, H., Hansson, H.C., Väkevä, M., Koponen, I. K., Buzorius, G., and Kulmala, M.: Physical characterization of aerosol particles during nucleation events, Tellus, 53B, 344-358, 2001.

Armendariz, A. and Leith, D.: Concentration measurement and counting efficiency for the aerodynamic particle sizer 3320 , J Aerosol Sci., 33, 133-148, 2002.

Birmili, W., Wiedensohler, A., Heintzenberg, J., and Lehmann, K.: Atmospheric particle number size distribution in Central Europe: statistical relations to air masses and meteorology, J. Geophys. Res., 106, 32 005-32 018, 2001.

Boy, M., Kulmala, M., Ruuskanen, T. M., Pihlatie, M., Reissell, A., Aalto, P. P., Keronen, P., Dal Maso, M., Hellen, H., Hakola, H., Jansson, R., Hanke, M., and Arnold, F.: Sulphuric acid closure and contribution to nucleation mode particle growth, Atmos. Chem. Phys. Discuss., 4, 6341-6377, 2004,

SRef-ID: 1680-7375/acpd/2004-4-6341.

Brockmann, J.: Sampling and Transport of Aerosols, in: Aerosol Measurement: Principles, Techniques and Applications, 2nd Edition, edited by: Baron, P. A. and Willeke, K., John Wiley and Sons, New York, 143.195, 2001.

Carmichael, G. R., Ferm, M., Thongboonchoo, N., Woo, J.-H., Chan, L. Y., Murano, K., Viet, P. H., Mossberg, C., Bala, R., Boonjawat, J., Upatum, P., Mohan, M., Adhikary, S. P., Shrestha, A. B., Pienaar, J. J., Brunke, E. B., Chen, T., Jie, T., Guoan, D., Peng, L. C., Dhiharto, S., Harjanto, H., Jose, A. M., Kimani, W., Kirouane, A., Lacaux, J.-P., Richard, S., Barturen, O., Cerda, J. C., Athayde, A., Tavares, T., Cotrina, J. S., and Bilici, E.: Measurements of sulfur dioxide, ozone and ammonia concentrations in Asia, Africa, and South America using passive samplers, Atmos. Environ., 37, 1293-1308, 2003.

Charlson, R. J., Lovelock, J. E., Andreas, M. D., and Warren, S. G.: Oceanic phytoplankton, atmospheric sulphur, cloud albedo and climate, Nature, 326, 655-661, 1987.

Dal Maso, M., Kulmala, M., Lehtinen, K., Mäkelä, J., Aalto, P., and O'Dowd, C.: Condensation and coagulation sinks and formation of nucleation mode particles in coastal and boreal forest boundary layers, J. Geophys. Res., 107, doi:10.1029/2001JD001053, 2002.

Donaldson, K., Li, X., and MacNee, W.: Ultrafine (nanometre) particle mediated lung injury, J. Aerosol Sci., 29, 553-560, 1998.

Fuchs, N. A. and Sutugin, A. G.: High-dispersed aerosols in Topics in Current Aerosol Research, edited by: Hidy, G. M. and Brock, J. R., Pergamon, Oxford, 2, 1-60, 1971.

Griffin, R., Cocker III, D., Seinfeld, J., and Dabdub, D.: Estimate of global atmospheric organic aerosol from oxidation of biogenic hydrocarbons, Geophys. Res. Lett., 26, 2721-2724, 1999.

Jokinen, V. and Mäkelä, J. M.: Closed loop arrangement with critical orifice for DMA sheath/excess flow system, J. Aerosol Sci., 
28, 643-648, 1997.

Kavouras, I., Mihalopoulos, N., and Stephanou, E.: Formation of atmospheric particles from organic acids produced by forests, Nature, 395, 686-693, 1998.

Kerminen, V.-M., Pirjola, L., and Kulmala, M.: How significantly does coagulation scavening limit atmospheric particle production?, J. Geophys. Res., 106, 24 119-24 125, 2001.

Koponen, I. K., Virkkula, A., Hillamo, R., Kerminen, V.-M., and Kulmala, M.: Number size distributions and concentrations of the continental summer aerosols in Queen Maud Land, Antarctica, J. Geophys. Res., 108, doi:10.1029/2003JD003614, 2003.

Kulmala, M.: Nucleation as an aerosol physical problem, $\mathrm{PhD}$ thesis, University of Helsinki, 1988.

Kulmala, M.: How Particles Nucleate and Grow, Science, 302, 1000-1001, 2003.

Kulmala, M., Toivonen, A., Mäkelä, J. M., and Laaksonen, A.: Analysis of the growth of nucleation mode particles in Boreal Forest, Tellus B, 50, 449-462, 1998.

Kulmala, M., Korhonen, P., Laakso, L., and Pirjola, L.: Nucleation in boreal forest boundary layer, Environ. Chem. Phys., 22, 4653, 2000.

Kulmala, M., Dal Maso, M., Mäkelä, J., Pirjola, L., Väkevä, M., Aalto, P., Miikkulainen, P., Hämeri, K., and O'Dowd, C.: On the formation, growth and composition of nucleation mode particles, Tellus B, 53, 479-490, 2001a.

Kulmala, M., Hämeri, K., Aalto, P., Mäkelä, J., Pirjola, L., Nilsson, E. D., Buzorius, G., Rannik, Ü., Dal Maso, M., Seidl, W., Hoffman, T., Janson, R., Hansson, H.-C., Viisanen, Y., Laaksonen, A., and O'Dowd, C. D.: Overview of the international project on biogenic aerosol formation in the boreal forest (BIOFOR), Tellus B, 53, 324-343, 2001b.

Kulmala, M., Vehkamäki, H., Petäjä, T., Dal Maso, M., Lauri, A., Kerminen, V.-M., Birmili, W., and McMurry, P.: Formation and growth rates of ultrafine atmospheric particles: a review of observations, J. Aerosol Sci., 35, 143-176, 2004.

Lack, D. A., Tie, X. X., Bofinger, N., Wiegand, A., and Madronich, S.: Seasonal variability of secondary organic aerosol: A global modeling study, J. Geophys. Res., 109, doi:10.1029/2003JD003418, 2004.

Mäkelä, J. M., Aalto, P., Jokinen, V., Pohja, T., Nissinen, A., Palmroth, S., Markkanen, T., Seitsonen, K., Lihavainen, H., and Kulmala, M.: Observations of ultrafine aerosol particle formation and growth in boreal forest, Geophys. Res. Lett., 24, 1219-1222, 1997.

Mertes, S., Schröder, F., and Wiedensohler, A.: The particle detection efficiency curve of the TSI-3010 CPC as a function of temperature difference between saturator and condenser, Aerosol Sci. Technol., 23, 257-261, 1995.

Mönkkönen, P., Koponen, I. K., Lehtinen, K. E. J., Hämeri, K., Uma, R., and Kulmala, M.: Measurements in a highly polluted Asian mega city: Observations of aerosol number size distributions, modal parameters and nucleation events, Atmos. Chem. Phys., 5, 57-66, 2005,

\section{SRef-ID: 1680-7324/acp/2005-5-57.}

O’Dowd, C. D., McFiggans, G., Creasey, D., Pirjola, L., Hoell, C., Smith, M., Allan, B., Plane, J., Heard, D., Lee, J., Pilling, M., and Kulmala, M.: On the photochemical production of new particles in the coastal boundary layer, Geophys. Res. Lett., 26, 1707$1710,1999$.
Pirjola, L., Kulmala, M., Wilck, M., Bischoff, A., Stratmann, F., and Otto, E.: Effects of aerosol dynamics on the formation of sulphuric acid aerosols and cloud condensation nuclei, J. Aerosol Sci., 30, 1079-1094, 1999.

Quant, F. R., Caldow, R., Sem, G. J., and Addison, T. J.: Performance of condensation particle counters with three continuous flow designs, J. Aerosol. Sci., 23, S405-S408, 1992.

Rotstayn, L. D. and Lohmann, U.: Simulation of the tropospheric sulfur cycle in a global model with a physically based cloud scheme, J. Geophys. Res., 107, doi:10.1029/2002JD002128, 2002.

Stanier, C., Khlystov, A. Y., and Pandis, S. N.: Nucleation events during the Pittsburgh Air Quality Study: description and relation to key meteorological, gas phase, and aerosol parameters, Aerosol Sci. Technol., 38 (S1), 253-264, 2004.

Stolzenburg, M. R.: An ultrafine aerosol size distribution measuring system, PhD thesis, University of Minnesota, 1988.

Stolzenburg, M. and McMurry, P.: An ultrafine aerosol condensation nucleus counter, Aerosol Sci. Technol., 14, 48-65, 1991.

Tsigaridis, K. and Kanakidou, M.: Global modelling of secondary organic aerosol in the troposphere: sensitivity analysis, Atmos. Chem. Phys., 3, 1849-1869, 2003,

SRef-ID: 1680-7324/acp/2003-3-1849.

Väkevä, M., Hämeri, K., Puhakka, T., Nilsson, E., Hohti, K., and Mäkelä, J.: Effects of meteorological processes on aerosol particle size distribution in an urban background area, J. Geophys. Res., 105, 9807-9821, 2000.

Vehkamäki, H., Dal Maso, M., Hussein, T., Flanagan, R., Hyvärinen, A., Lauros, J., Merikanto, J., Mönkkönen, P., Pihlatie, M., Salminen, K., Sogacheva, L., Thum, T., Ruuskanen, T., Keronen, P., Aalto, P., Hari, P., Lehtinen, K., and Kulmala, M.: Atmospheric particle formation events at Värriö measurement station in Finnish Lapland 1998-2002, Atmos. Chem. Phys., 4, 2015-2023, 2004,

SRef-ID: 1680-7324/acp/2004-4-2015.

Weber, R. J., Marti, J., McMurry, P. H., Eisele, F., Tanner, D. J., and Jefferson, A.: Measured atmospheric new particle formation rates: implications for nucleation mechanisms, Chem. Eng. Comm., 151, 53-64, 1996.

Weber, R. J., Marti, J. J., McMurry, P. H., Eisele, F. L., Tanner, D. J., and Jefferson, A.: Measurements of new particle formation and ultrafine particle growth rates at a clean continental site, J. Geophys. Res., 102, 4373-4385, 1997.

Wiedensohler, A.: An approximation of the bipolar charge distribution for particles in the submicron range, J. Aerosol Sci., 19, 387-389, 1988.

Winkler, P. M., Vrtala, A., Wagner, P. E., Kulmala, M., Lehtinen, K. E. J., and Vesala, T.: Mass and thermal accommodation during gas-liquid condensation of water, Phys. Rev. Lett., 93, 075701, 2004.

Winklmayr, W., Reischl, G., Lindner, A., and Berner, A.: A new electromobility spectrometer for the measurement of aerosol size distributions in the size range from 1 to $1000 \mathrm{~nm}$, J. Aerosol Sci., 22, 289-296, 1991. 